\title{
Invited Review: Advances in Starter Cultures and Cultured Foods ${ }^{1}$
}

\author{
T. M. Cogan, ${ }^{*}$ T. P. Beresford, ${ }^{\star}$ J. Steele,† J. Broadbent,‡ N. P. Shah, $\S$ and Z. Ustunol\# ${ }^{2}$ \\ *Moorepark Food Reseach Centre, Teagasc, Fermoy, Ireland \\ †University of Wisconsin, Madison 53706 \\ ¥Utah State University, Logan 84322 \\ §Victoria University, Melbourne, Victoria, Australia \\ \#Michigan State University, E. Lansing 48842
}

\begin{abstract}
With 2005 retail sales close to $\$ 4.8$ million, cultured dairy products are driving the growth of dairy foods consumption. Starter cultures are of great industrial significance in that they play a vital role in the manufacturing, flavor, and texture development of fermented dairy foods. Furthermore, additional interest in starter bacteria has been generated because of the data accumulating on the potential health benefits of these organisms. Today, starter cultures for fermented foods are developed mainly by design rather than by the traditional screening methods and trial and error. Advances in genetics and molecular biology have provided opportunities for genomic studies of these economically significant organisms and engineering of cultures that focuses on rational improvement of the industrially useful strain. Furthermore, much research has been published on the health benefits associated with ingesting cultured dairy foods and probiotics, particularly their role in modulating immune function. The aim of this review is to describe some of the major scientific advances made in starter and nonstarter lactic acid bacteria during the past $10 \mathrm{yr}$, including genomic studies on dairy starter cultures, engineering of culture attributes, advances in phage control, developments in methods to enumerate lactic acid bacteria and probiotics in dairy foods, and the potential role of cultured dairy foods in modulation of immune function.
\end{abstract}

Key words: starter culture, historical overview, lactic acid bacteria, probiotic

\section{NONSTARTER LACTIC ACID BACTERIA}

Nonstarter lactic acid bacteria (NSLAB) are lactic acid bacteria that are not part of the normal starter

\footnotetext{
Received November 16, 2006.

Accepted May 8, 2007.

${ }^{1}$ This paper is a summary of the symposium presented at the American Dairy Science Association meeting in Minneapolis, Minnesota, on July 9, 2006.

${ }^{2}$ Corresponding author: ustunol@msu.edu
}

bacteria added to the milk for cheese making. They include lactobacilli (mainly), enterococci, and (occasionally) pediococci and leuconostocs and were first isolated from cheese in 1912. The NSLAB are probably present in all cheese and, during ripening, grow from levels of $10^{2}$ to $10^{4} \mathrm{cfu} / \mathrm{g}$ to $\sim 10^{8} \mathrm{cfu} / \mathrm{g}$ after manufacture. A doubling time of $8.5 \mathrm{~d}$ has been found for NSLAB in Cheddar cheese ripened at $8^{\circ} \mathrm{C}$ (Jordan and Cogan, 1993).

Beresford and Williams (2004) have summarized the NSLAB that have been identified in $>50$ varieties of cheese. In most cheeses (regardless whether they are made from raw or pasteurized milk), the dominant organisms were facultatively homofermentative lactobacilli (FHL) especially Lactobacillus casei, Lactobacillus plantarum, and Lactobacillus curvatus. Obligate heterofermenters, particularly Lactobacillus brevis, were found in lower numbers. Previous reviews of NSLAB include those of Peterson and Marshall (1990) and Fox et al. (1998).

\section{Taxonomy}

The taxonomy of $L b$. casei is problematic and has been reviewed by Dellaglio et al. (2002). The type strain of $L b$. casei ( $L b$. casei ATCC 393) is, in fact, a strain of Lactobacillus zeae and does not hybridize with authentic strains of Lb. casei. For this reason, Collins et al. (1989) proposed that the latter strains be called Lactobacillus paracasei, whereas Dicks et al. (1996) proposed that these strains still be considered as $L b$. casei but that $L b$. casei ATCC 334, which was originally isolated from Emmental cheese, be considered the type strain of $L b$. casei and that the name Lb. paracasei be rejected. Most strains isolated from cheese are Lb. (para)casei. Lactobacillus casei ATCC 334 has been sequenced and is available on the BLAST Web site (http://www.ncbi.nlm.nih.gov/BLAST/). Vasquez et al. (2005) used restriction enzyme analysis, temporal temperature gradient gel electrophoresis, and ribotyping to evaluate 37 strains of $L b$. casei, $L b$. paracasei, Lb. zeae, and Lb. rhamnosus, many of which 
were isolated from cheese, including $L b$. casei ATCC 393. Sequencing the $16 \mathrm{~S}$ rRNA genes showed that polymorphisms were present. This heterogeneity provides one explanation for the difficulty encountered in obtaining clear-cut distinctions between $L b$. casei and Lb. paracasei.

\section{Detection}

Direct plating on selective media such as de Man, Rogosa, and Sharpe (MRS) agar adjusted to $\mathrm{pH} 5.4$ or Lactobacillus selection medium is normally used to detect NSLAB. Obligately heterofermentative lactobacilli and leuconostocs are vancomycin resistant and can be isolated using nutritionally suitable media containing vancomycin (20 to $30 \mu \mathrm{g} / 100 \mathrm{~mL}$ ). However, many FHL and pediococci are also vancomycin resistant, due to production of peptidoglycan precursors ending in D-lactate rather than D-alanine. A potential problem in counting NSLAB is that the low numbers are occluded in a solid matrix raising important questions-are they all in the aqueous phase, can they move freely in the aqueous phase, and do they form microcolonies? Molecular methods, including random amplified polymorphic DNA (RAPD)-PCR (Fitzsimons et al., 1999; Baruzzi et al., 2000; deAngelis et al., 2001; Somers et al., 2001; Antonsson et al., 2003; Sanchez et al., 2005), repetitive-element (Rep)-PCR (Berthier et al., 2001), temporal temperature gradient gel electrophoresis (TTGE; Antonsson et al., 2003), denaturing gradient gel electrophoresis (DGGE; Ogier et al., 2002), single strand conformation polymorphism (SSCP; Duthoit et al., 2003), and SDS-PAGE (deAngelis et al., 2001) are also used.

\section{Sources}

Milk is the major source of NSLAB in production of the raw milk cheese Comté cheese (Berthier et al., 2001). Many FHL resist pasteurization implying that raw milk is also a likely source in cheese made from pasteurized milk (Jordan and Cogan, 1999). Lactobacilli have also been isolated from drains, floors near vats, new vats, counter tops, vacuum packing machines, molds, and biofilms (Somers et al., 2001); the latter could be important when vats are refilled without being adequately cleaned.

The number of different strains of each species of FHL involved has been studied to a limited extent. Fitzsimons et al. (1999) found an average of 7 strains (mainly Lb. casei) per cheese and that cheese from different factories had different strains, whereas Crow et al. (2001) found that $91 \%$ of strains isolated from 6 factories over a 24-mo period comprised 6 strains (mainly $L b$. casei and $L b$. rhamnosus); 1 strain dominated $10 \%$ of the cheeses. These researchers also found the same strain in cheese from consecutive seasons, suggesting that the cheese factory environment was their source. Crow et al. (2001) found that 7 of 24 combinations of 2 to 4 strains from an empirical selection of 24 strains gave consistent improvement in cheese flavor.

\section{Growth in Milk}

There is very little information on the growth of FHL in milk. Khalid and Marth (1990) studied 3 strains of Lb. casei and 6 strains of Lb. plantarum. After $1 \mathrm{~d}$ at $37^{\circ} \mathrm{C}$, the $\mathrm{pH}$ values ranged from 5.8 to 6.0 . Thereafter, the $\mathrm{pH}$ values decreased slowly and after $6 \mathrm{~d}$, ranged from 4.5 to 6 for the $L b$. plantarum strains and $\mathrm{pH} 4$ to 5 for the $L b$. casei strains.

Because NSLAB are prototrophic for several amino acids and milk is deficient in free amino acids, proteinase activity is important for their growth in milk. $\beta$ Casein was preferentially hydrolyzed over $\alpha_{\mathrm{s}}$-casein by the $L b$. plantarum strains, whereas only one strain of $L$. case $i$ showed any activity on $\beta$-casein (Khalid and Marth, 1990). Naes and Nissen-Meyer (1992) purified the proteinase of $L b$. (para)casei ssp. (para)casei NCDO 151. It eluted at similar salt concentrations as the lactococcal proteinase in anion-exchange and hydrophobic interaction chromatography, and had the same N-terminal sequence as that of the lactococcal proteinase, at least from the second to the ninth AA residue (the first one gave an equivocal result). In addition, the respective prt genes of $L b$. (para)casei and Lactococcus lactis showed extensive homology suggesting a strong relationship between them.

\section{Metabolism}

Lactobacillus casei and $L b$. plantarum ferment lactose by the phosphoenol pyruvate phosphotransferase system, in which phosphoenol pyruvate is the source of energy in a complex series of reactions initially yielding lactose-P on transport across the cell wall, which is then hydrolyzed by phospho- $\beta$-galactosidase to glucose and galactose-6-phosphate. Both sugars are then fermented by glycolysis yielding $2 \mathrm{~mol}$ of lactic $\mathrm{acid} / \mathrm{mol}$ of hexose used. In contrast, gluconate is fermented by FHL by the heterofermentative pathway, yielding $1 \mathrm{~mol}$ of $\mathrm{CO}_{2}, 1 \mathrm{~mol}$ of ethanol/acetic acid, and $1 \mathrm{~mol}$ of lactic acid per mol used. For this reason, these lactobacilli are called facultative heterofermentative lactobacilli. Both L- and D-lactate are produced by stereospecific NADH-dependent lactate dehydrogenases (LDH) in varying ratios. A lactate racemase is also 
involved in producing D-lactate, because knockout of the D-LDH in $L b$. plantarum NCIMB 8826 still resulted in D-lactate production (Goffin et al., 2005). Knockout of both L- and D-LDH in the strain resulted in acetoin (rather than lactate) production, peptidoglycan precursors ending in D-alanine (rather than Dlactate), and vancomycin sensitivity (Ferain et al., 1996). A 6-gene operon was identified but no clear function could be attributed to any of the genes, except one that encoded a membrane protein of the aquaglyceroporin family. The NSLAB are also responsible for converting L-lactate to D-lactate during cheese ripening, a reaction that is slower at higher salt concentrations. When sufficient D-lactate is formed, Ca D-lactate precipitates as white spots in cheese because Ca Dlactate is more insoluble than Ca L-lactate.

The FHL are unable to use citrate as an energy source but are able to metabolize it in the presence of a fermentable sugar by a similar pathway to that of $\mathrm{Cit}^{+}$lactococci (Palles et al., 1998). Faster catabolism of citrate occurs in the presence of galactose than of glucose or lactose suggesting that catabolite repression by glucose may be operating.

Succinate is a flavor enhancer found in Emmental cheese at levels of 0.8 to $1.4 \mathrm{mg} / \mathrm{g}$. Kaneuchi et al. (1988) tested 144 strains representing 15 species of lactobacilli for succinate production after incubation in MRS for $2 \mathrm{~d}$ at $35^{\circ} \mathrm{C}$. Some species, particularly Lactobacillus reuteri and Lactobacillus cellobiosus but not $L b$. plantarum or $L b$. (para)casei, produced succinate. Lindgren et al. (1990) found that all 5 strains of $L b$. plantarum (silage inoculants) tested could produce succinate from a mixture of lactate and citrate in a chemically defined medium over long periods (70 d) at $28^{\circ} \mathrm{C}$, oxidizing the lactate to acetate and formate (pyruvate-formate lyase activity) and reducing the citrate to succinate (citrate lyase, malate dehydrogenase, fumarase, and fumarate reductase activities). Citrate was not used as energy source in the absence of glucose. Dudley and Steele (2005) found that some strains of $L b$. plantarum, but not Lb. casei or Lb. rhamnosus, produced succinate in $100 \mathrm{~m} M$ phosphate, $\mathrm{pH}$ 7.0, containing citrate and lactate. Succinate can also be produced from aspartate and propionate or lactate by propionibacteria (Crow, 1986).

Oude Elferink et al. (2001) showed that Lactobacillus buchneri and the closely related species, Lactobacillus parabuchneri, but not Lactobacillus kefir or Lb. plantarum, were able to stoichiometrically degrade lactate into $0.5 \mathrm{~mol}$ each of acetate, $\mathrm{CO}_{2}$, and 1,3 propanediol at $\mathrm{pH} 4.0$. No activity was observed at $\mathrm{pH}$ $>5.8$. Only very small amounts of growth occurred from optical density 0.04 to 0.18 ( $\sim 2$ generations). Whether this reaction occurs in cheese has not been determined.
Lactobacilli and pediococci are able to produce acetate and $\mathrm{CO}_{2}$ from lactate in the presence of $\mathrm{O}_{2}$ under Cheddar cheese ripening conditions (Thomas, 1987). This system depends on the $\mathrm{O}_{2}$ transfer rate of the plastic wrapper used and the ripening time.

\section{Growth Substrates in Cheese}

The NSLAB require an energy source for growth. All the lactose in cheese is metabolized within the first weeks of ripening. Thus, sugars in lysed cells and in the milk fat globule membrane, and citrate and arginine have been suggested as possible substrates. Citrate is not used as an energy source by NSLAB although it is metabolized by many if sugars are also present. Arginine is an unlikely source for reasons described below. Residual lactose is still the most likely substrate because only about $2 \mathrm{mg} / \mathrm{g}$ would be required for growth to $10^{7}$ to $10^{8} \mathrm{cfu} / \mathrm{g}$.

Lactobacillus plantarum, Lb. brevis, Leuconostoc mesenteroides, Pediococcus acidilactici, and Pediococcus pentosaceus cannot grow on D-ribose as the sole source of fermentable carbohydrate, but can metabolize it if glucose is also present (Westby et al., 1993). Increased biomass over that on glucose alone was produced, implying that these species obtain energy from ribose metabolism. How this occurs is not clear but the results suggest that ribose from RNA degradation in lysed cells would not be a substrate for growth in cheese because insufficient lactose or other fermentable sugar would be present.

\section{Arginine Metabolism and Biogenic Amine Production}

Many NSLAB can metabolize arginine by the deininase pathway forming ornithine, citrulline, $\mathrm{NH}_{3}$, and $\mathrm{CO}_{2}$, and generating $1 \mathrm{~mol}$ of ATP from each mol of arginine used in the process (Poolman, 1993). Theoretically, therefore, arginine is a potential energy source for lactic acid bacteria (LAB). Laht et al. (2002) found a curvilinear relationship between the log of the NSLAB and the concentration of ornithine in Swiss-type cheese. If arginine were being used as an energy substrate, one would expect a linear relationship; however, arginine could have been used in other reactions. Lactic acid bacteria have considerable requirements for amino acids (and vitamins) and so most media contain sources of amino acids such as yeast extract and peptones. Such constituents also contain residual sugars and, to our knowledge, no one has shown that LAB actually utilize arginine in chemically defined media without another energy source. Laht et al. (2002) did measure arginine in a tryptone and yeast extract me- 
dium and showed that growth over $9 \mathrm{~d}$ at $30^{\circ} \mathrm{C}$ increased from 0.03 to 0.13 (i.e., 2 generations) during which time arginine decreased from 0.45 to $0.24 \mathrm{mM}$; $2.5 \mathrm{~m} M$ lactate was also produced, indicating that residual sugar was present in the medium.

Many NSLAB (e.g., Lb. buchneri) have the potential to produce biogenic amines, particularly histamine from histidine (Sumner et al., 1985); in addition, tyramine (from tyrosine), cadaverine (from lysine), and putrescine (from ornithine) can be produced. Histamine and tyramine are metabolised by Brevibacterium linens during ripening of smear-ripened cheese (Leuschner and Hammes, 1998).

\section{NSLAB and Cheese Flavor Formation}

Raw milk cheeses are considered to have better flavor than those made from pasteurized milk, indicating that the raw milk microflora (including NSLAB) and perhaps heat-sensitive enzymes have an effect on flavor.

Because NSLAB grow to considerable numbers in cheese and many cheeses are ripened for long periods, the effect that selected strains of NSLAB have on cheese flavor development has been intensively studied. The early results (reviewed by Peterson and Marshall, 1990) were equivocal. This may have been due to the lack of reliable selective media for lactobacilli, the inability to distinguish between the adventitious NSLAB and those deliberately added, and the fact that many mother and bulk cultures would have been contaminated with lactobacilli, leading to control cheese with high levels of lactobacilli. Results from recent studies generally show a positive effect of FHL on flavor (Puchades et al., 1989; Broome et al., 1990; McSweeney et al., 1993; Lynch et al., 1996; Swearingen et al., 2001; Antonsson et al., 2003).

Enterococci, particularly Enterococcus faecalis, Enterococcus faecium, and Enterococcus casseliflavus, are found in high numbers $\left(\sim 10^{7} \mathrm{cfu} / \mathrm{g}\right)$ in many cheeses made around the Mediterranean and are thought to have a positive influence on flavor (Franz et al., 1999). They grow during Cheddar cheese manufacture, and, although some of them showed increased proteolysis, there was no statistical effect on flavor (Rea et al., 2004). Pediococcus pentosaceus improves the flavor of the soft Greek cheese, Teleme, which is made with yogurt starter cultures (Tzanetakis et al., 1991).

Autolysis by starter bacteria and subsequent release of intracellular enzymes is considered important in developing cheese flavor. Little work has been done on autolysis by NSLAB but little lysis occurs during cheese ripening (Fox et al., 2000). In vitro, more autolysis occurs in exponential phase cells of $L b$. casei than in stationary phase cells (Kang et al., 1998). Bacteriocins also involve cell lysis but their potential role in causing lysis of NSLAB during cheese ripening has not been considered except for the report of Ryan et al. (1996), who showed that the use of a bacteriocin-producing starter prevented the growth of NSLAB in cheese. Cell lysis by virulent phage for $L b$. plantarum and $L b$. casei has been reported (Kashige et al., 2000; Capra et al., 2006). The effect of both bacteriocins and phage on lysis of FHL during cheese ripening on flavor development needs to be evaluated.

Yvon et al. (1998) showed that addition of $\alpha$-ketoglutarate $(\boldsymbol{\alpha}-\mathbf{K G})$ to cheese curd increased glutamate production, decreased the concentration of other amino acids, and improved the aroma (the cheese was not tasted). This has led to considerable emphasis on flavor formation from amino acid metabolism, particularly methionine, the major S-containing amino acid in milk proteins. Sulfur-containing compounds (e.g., methanethiol, dimethyl sulfide, trimethyl sulfide) contribute to the cheesy, cabbagy, and garlic flavors of cheese. These compounds are produced in very small amounts but they have very low flavor threshold levels. Methanethiol is formed in 2 ways from methionine: directly via a methionine- $\gamma$-lyase (which has been purified from B. linens and Lc. lactis) or indirectly through a methionine amino transferase (AT). Only 5 out of 22 strains of $L b$. plantarum and 2 out of 7 strains of Lb. casei showed AT activity (Amarita et al., 2001), which also requires an amino group acceptor. $\alpha$-Ketoglutarate produced from glutamate by glutamate dehydrogenase (GDH) is considered the most important source and its formation the rate-limiting step in cheese ripening.

Reports on GDH activity by cheese-associated bacteria are limited. Tanous et al. (2002) found GDH in 4 of 10 strains of $L b$. casei and 13 of 14 strains of $L b$. plantarum; however, it was not determined if the producing strains enhanced flavor production in cheese. In vitro, flavor formation by Lc. lactis and GDH-containing lactobacilli has been shown with lactobacilli producing $\alpha$-keto and hydroxyl acids from phenylalanine, leucine, and methionine in the presence of glutamate from which the lactococci produced flavorful carboxylic acids (Kieronczyk et al., 2003). It would be interesting to study the effects of an FHL containing both AT and GDH activities on cheese ripening.

After vanillin, benzaldeyde is the second most important flavor compound in the flavor industry (Nierop Groot and de Bont, 1998). Lactobacillus plantarum produces it by transaminating phenylalanine to phenylpyruvate, from which benzaldehyde is produced by chemical degradation. Addition of $\mathrm{Cu}^{2+}$ also resulted 
Table 1. Genome sequencing projects for dairy-related lactic acid bacteria and other species

\begin{tabular}{|c|c|c|c|c|}
\hline Species & Strain & $\begin{array}{c}\text { Genome size } \\
(\mathrm{Mb})\end{array}$ & Project sponsor ${ }^{1}$ & $\begin{array}{c}\text { Public } \\
\text { access? }^{1}\end{array}$ \\
\hline Lactobacillus acidophilus & ATCC700396 & 2.0 & Dairy Management, Inc. and Rhodia, Inc. (US) & No \\
\hline Lb. brevis & ATCC 367 & 2.0 & JGI-LABGC (US) & Yes \\
\hline Lb. casei & BL23 & 2.6 & INRA (FRA) & No \\
\hline Lb. delbrueckii ssp. bulgaricus & ATCCBAA-365 & 2.3 & JGI-LABGC (US) & Yes \\
\hline Lb. delbrueckii ssp. bulgaricus & ATCC11842 & 2.3 & INRA and Genoscope (FRA) & No \\
\hline Lb. delbrueckii ssp. bulgaricus & DN-100107 & 2.1 & Danone Vitapole (FRA) & No \\
\hline Lb. helveticus & DPC 4571 & Not reported & Teagasc and University College, Cork (IRL) & No \\
\hline Lb. johnsonii & NCC533 & 2.0 & Nestlé (CHE) & Yes \\
\hline Lb. plantarum & WCFS1 & 3.3 & Wageningen Center for Food Sciences (NLD) & Yes \\
\hline Lb. rhamnosus & HN001 & 2.4 & Fonterra Research Center, NZ & No \\
\hline Lactococcus lactis ssp. cremoris & SK11 & 2.3 & JGI-LABGC (US) & Yes \\
\hline Lc. lactis ssp. cremoris & MG1363 & 2.6 & Univ. Groningen (NLD); INRA (FRA) & No \\
\hline Lc. lactis ssp. lactis & IL1403 & 2.3 & INRA and Genoscope (FRA) & Yes \\
\hline S. thermophilus & CNRZ1066 & 1.8 & INRA (FRA) & No \\
\hline \multicolumn{5}{|l|}{ Other dairy-related bacteria: } \\
\hline Bifidobacterium longum & NCC2705 & 2.3 & Nestlé (CHE) & Yes \\
\hline B. longum & DJ010A & 2.1 & JGI-LABGC (US) & Yes \\
\hline Bifidobacterium breve & NCIMB8807 & 2.4 & University College, Cork (IRL) & No \\
\hline Brevibacterium linens & ATCC9174 & 3.0 & JGI-LABGC (US) & Yes \\
\hline Propionibacterium freundenreichii & ATCC6207 & 2.6 & DSM Food Specialties (NLD) & No \\
\hline
\end{tabular}

${ }^{1}$ As of September 1, 2004. Country codes: US = United States; FRA = France; IRL = Ireland; CHE = Switzerland; NLD = Netherlands; $\mathrm{NZ}=$ New Zealand; BEL = Belgium. JGI-LABGC = Department of Energy Joint Genome Institute and Lactic Acid Bacteria Genomics Consortium.

in production of phenyl acetate, mandelate, and phenylglyoxylate from the phenylpyruvate.

Chemical degradation of the products of aromatic amino acid metabolism can impart off-flavors to cheese. Examples include skatole produced from indole-3-lactate, which, in turn is produced from tryptophan and phenyl acetate, and phenethanol and phenylpropionate produced from phenylalanine (Gumalla and Broadbent, 1999, 2001).

Lactobacillus plantarum isolated from silage also has the ability to produce antifungal compounds including 3 phenyllactate and 2 cyclic dipeptides (Strom et al., 2002). Whether this occurs in cheese has not been determined.

\section{Insights from Genomic Studies on Dairy LAB}

Genomes of LAB contain both plasmid and chromosomal DNA (Broadbent, 2001). The characterization of plasmids in LAB has been an ongoing area of study for the past $30 \mathrm{yr}$ (Broadbent, 2001). Characterization of LAB chromosomes began in the early $1970 \mathrm{~s}$; however, the most exciting developments in LAB genomics are now being fueled by nucleotide sequence information for complete genomes. Currently, the genome sequence is known or is being determined for more than 20 LAB (Table 1). The value of genome sequence infor- mation for dairy-related LAB cannot be overstated. This section will cover briefly some of the advances that the availability of genome sequences has already made possible.

Because of their economic relevance, many of these sequences are being mined for intellectual property and are not yet available to the general scientific community. Nonetheless, nucleotide sequence data is publicly available for more than half of the sequenced LAB strains (Makarova et al., 2006; Table 1), and 10 of the 14 publicly accessible sequences were contributed as part of a joint venture between the Department of Energy Joint Genome Institute and the US-based Lactic Acid Bacterial Genomics Consortium. Their mission is to advance academic and industrial research on LAB through release of genome sequence information for microorganisms prominently associated with the fermented foods industry.

There are 2 main foci in this section. The first is how the availability of genomic sequences has provided new insights to how LAB genomes have changed during evolution in the milk environment. The second is how genomic information can be used to further our understanding of dairy fermentations; this section is based on research conducted in collaboration between J. Steele and J. Broadbent. 
It is thought that LAB emerged 1.5 to 2.0 billion years ago, whereas the milk environment is a relatively recent environment. The milk environment certainly arose after the emergence of mammals (approximately 60 million years ago) and more likely became a viable environment for nonpathogenic microorganisms around the time that man domesticated dairy animals (approximately 10,000 yr ago; Fox and McSweeney, 2004). The availability of dairy LAB genomic sequences has shed new light on the evolution of these organisms to the milk new environment. Milk is a nutritionally rich, stable environment containing lactose as the primary carbohydrate and caseins as a rich potential source of amino acids; milk also contains most vitamins and minerals. Examination of dairy $\mathrm{LAB}$ genomes shows that gene loss or inactivation as well as metabolic simplification is a central component of the evolution of these organisms to milk (Bolotin et al., 2001, 2004; Makarova et al., 2006; van de Guchte et al., 2006). This is particularly true in genes involved in amino acid biosynthesis. Selective pressure during growth in milk has favored microorganisms that are capable of obtaining amino acids from caseins via their relatively complex proteolytic enzyme system and loss or inactivation of genes for de novo biosynthesis of amino acids. Additionally, it is clear that horizontal gene transfer, a process by which an organism transfers genetic material to different organisms, has played a significant role in the evolution of these organisms. For example, the ability to utilize lactose as an energy source has evolved independently in different dairy LAB via horizontal gene transfer. The availability of dairy LAB genomic sequences supports the view that these organisms have evolved from other $\mathrm{LAB}$ via gene loss or inactivation, as well as via horizontal gene transfer, rapidly resulting in organisms that are specialists for growth in milk (Bolotin et al., 2004; Makarova et al., 2006; van de Guchte et al., 2006).

The availability of genomic sequences has also allowed researchers to rapidly discern the metabolic potential of the sequenced strains. For example, because proteolysis plays such a critical part in cheese ripening, the Steele research group and collaborators spent more than a decade examining the proteolytic system of Lactobacillus helveticus CNRZ32 (Christensen et al., 1999; Broadbent and Steele, 2007). The outcome of these efforts was the characterization of 12 CNRZ32 genes that encode proteolytic enzymes (Table 2). Despite these concerted efforts, initial annotation of the CNRZ32 genome sequence revealed a large number of additional genes in CNRZ32 whose products are predicted to contribute to the proteolytic enzyme system of this bacterium (Table 2).
From our perspective, such data underscore both the power of genome sequence information for applied bacteriology, and the challenges one must face in interpreting and applying that information. Although sequencing efforts expanded the genetic database for the CNRZ32 proteolytic enzyme system by about 5 -fold, efforts to confirm and characterize all the new gene assignments will require more time and resources. Nonetheless, functional analysis of the newly discovered endopeptidase genes has already identified enzymes with important roles in the hydrolysis of bitter peptides in cheese (Sridhar et al., 2005).

The availability of multiple genome sequences within a species allows for the study of strain-specific traits. For example, a comparison of the complete genome sequences of 2 strains of Lactobacillus delbrueckii ssp. bulgaricus identified regions involved in bacteriophage resistance, a trait known to vary from strain to strain.

The availability of genome sequences also allows studies to follow global gene regulation via DNA microarrays. A major strength of this technology is that it provides a nonbiased global view of an organism's transcriptional response to an environment of interest. This unbiased holistic view consistently yields unexpected observations that ultimately lead to the identification of genes with critical functions in the physiological system of interest. Our initial study investigated expression of these genes during growth in milk compared with a rich laboratory medium (Smeianov et al., 2007). The array data showed growth of $L b$. helveticus CNRZ32 in milk induced genes encoding cell-envelope proteinases, oligopeptide transporters, and endopeptidases, as well as enzymes for lactose, cysteine, and hypothetical phosphoserine utilization pathways, de novo synthesis, and salvage pathways for purines and pyrimidines, and other functions. The identification of a pathway for the utilization of serinephosphate (Figure 1) during growth of Lb. helveticus CNRZ32 in milk was an unexpected. However, given the relative abundance of serine-phosphate residues in casein, this pathway likely represents a readily explained adaptation of $L b$. helveticus to the milk environment.

Access to genomic information has provided researchers with an unprecedented opportunity to refine old, and develop new, hypotheses concerning how LAB effect the conversion of milk into a variety of fermented dairy products. However, testing these hypotheses is likely to take several years. Then, of course, perhaps the greatest challenge remains-taking this new knowledge and converting it into new or improved products for the consumer. 
Table 2. Components of the Lactobacillus helveticus CNRZ32 proteolytic enzyme system: A look before and after genome sequence determination

\begin{tabular}{ll}
$\begin{array}{l}\text { Genes identified and characterized } \\
\text { before sequencing project }\end{array}$ & \multicolumn{1}{c}{$\begin{array}{c}\text { Genes identified upon completion } \\
\text { of the draft genome sequence }\end{array}$} \\
\hline $\begin{array}{l}\text { Proteinases } \\
\text { prtH }\end{array}$ & prtH2 plus 9 additional proteases \\
$\begin{array}{l}\text { Endopeptidases } \\
\text { pepE, pepO, pep } O 2 \text { endopeptidases }\end{array}$ & pepE2, pepF, pepO3, plus 2 glycoproteins \\
$\begin{array}{l}\text { Aminopeptidases } \\
\text { pepC, pepN, pepX }\end{array}$ & pepC2 plus 7 additional aminopeptidases \\
$\begin{array}{l}\text { Di-Tripeptidases } \\
\text { pepD, pepI, pep } Q, p e p R\end{array}$ & pepD2, pepD3, pepD4, pepQ2, pepT1, and pepT2 \\
Other & Oligo- and di-tripeptide transport systems: \\
& oppA, oppA2, oppB- $D$, oppF, and $d t p A, d t p A 2$, and $d t p T$ \\
& Multiple amino acid transporters \\
\hline
\end{tabular}

\section{Engineering Culture Attributes}

Metabolic engineering of cells is founded upon the power to precisely establish or redirect cellular functions through DNA manipulation. Today, the ability to genetically manipulate or engineer animals, plants, and microorganisms to manufacture, modify, or improve products or processes has grown into a multibillion dollar enterprise that has revolutionized the pharmaceutical, chemical, and agricultural industries. Many of the most exciting and successful applications involve microbial products. Although the use of recombinant DNA (rDNA)-derived microbial products in agricultural and food systems is commonplace, a similar situation does not apply to the use of live, rDNA-containing microbial cells. When we consider potential applications for genetically modified dairy cultures, it

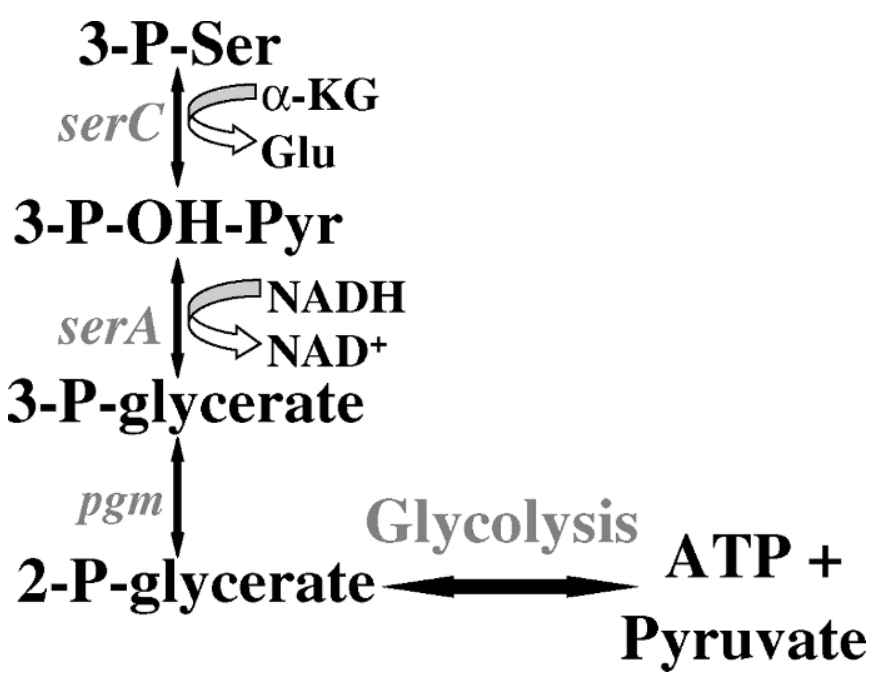

Figure 1. Proposed metabolic pathway for the metabolism of serine-phosphate by Lactobacillus helveticus CNRZ32. $\alpha$-KG $=\alpha$-ketoglutarate; SerA = phosphoglycerate dehydrogenase; SerC = phosphoserine aminotransferase; $\mathrm{pgm}=$ phosphoglycerate mutase. is important to recognize a few key principles. First, starter technology in dairy foods began in the late 19th century, and a long history of their safe application in human food has afforded GRAS (Generally Recognized as Safe) status to these bacteria. Moreover, current knowledge of starter physiology and genetics has already identified clear strategies to improve the industrial performance of these microbes. In some cases, genetic strain improvements can be effected by means that do not require the introduction and expression of rDNA molecules. Two examples of genetic improvements that reflect these criteria and have already been implemented by industry involve strategies to enhance phage-resistance and diacetyl production in lactococci.

\section{Bacteriophage Resistance}

Bacteriophages (phage) are viruses that attack and can destroy bacterial cells. The inhibitory effect of phages on dairy fermentations has been recognized for more than $60 \mathrm{yr}$, and their destructive impact has focused worldwide attention on molecular genetics and evolution of LAB phages. Because industrial fermentations with Lc. lactis and Strep. thermophilus starters suffer the greatest incidence of loss, current understanding of LAB phage biology is based largely on phages infecting these 2 species (Garvey et al., 1995; Brüssow et al., 1998). In lactococci, bacteriophage resistance is one of several industrially important traits that may be encoded by plasmid DNA. Fortuitously, many lactococcal phage-resistance plasmids can also be transferred into other strains of Lc. lactis by conjugation (Klaenhammer and Fitzgerald, 1994). Because conjugation is a natural form of gene transfer, dairy LAB that are genetically improved by this method bypass most of the regulatory and sociopolitical issues associated with rDNA technology. Sanders and coworkers (1986) were the first to demonstrate the feasibility of introducing plasmid-coded phage defense 
mechanisms into commercial Cheddar cheese starter bacteria by conjugation, and this strategy has been emulated by other researchers around the world (Klaenhammer and Fitzgerald, 1994). As a result, conjugation-derived, phage-insensitive dairy starter cultures have been in commercial use for many years.

Although conjugation of native phage-resistance plasmids has been of great benefit to the dairy industry, the flexibility of this strategy is clearly limited to plasmids that can be transferred by this process. In some countries, this limitation has been overcome by electroporation with native phage-resistance plasmids, and starter lactococci that have been improved by this process are in commercial use.

\section{Metabolic Engineering for Diacetyl Production}

Diacetyl is an industrially important compound used to impart buttery flavor and aroma to many foods. Diacetyl is derived from citrate metabolism by LAB, and knowledge of the enzymology and genetics of citrate metabolism has identified several strategies to metabolically engineer Lc. lactis strains for enhanced diacetyl production (deVos, 1996). One effective avenue toward this end involves inactivation of the gene encoding $\alpha$-acetolactate decarboxylase ( $a l d B)$, the enzyme that converts $\alpha$-acetolactate to acetoin (Figure 1). This mutation promotes an accumulation of $\alpha$-acetolactate, the immediate precursor to diacetyl, which in turn leads to an increased level of diacetyl in the growth medium.

Although aldB inactivation can certainly be achieved by rDNA methodology (Swindell et al., 1996), naturally occurring aldB mutants can be isolated by growth selection in a medium containing leucine, but not valine. This approach is possible because $\alpha$-acetolactate is also an intermediate in leucine and valine biosynthesis, and leucine acts as an allosteric activator of $\alpha$-acetolactate decarboxylase (Goupil-Feuillerat et al., 1997). Thus, wild-type lactococci cannot grow in this medium because Leu stimulates the enzymatic conversion of $\alpha$-acetolactate to acetoin, leaving none to support Val biosynthesis. However, aldB mutants are able to synthesize $\mathrm{Val}$ in the presence of Leu, and so will continue to grow. Interestingly, industrial application of this strategy was initially limited by the finding that most commercial Lc. lactis strains are auxotrophic for branched-chain amino acids. To overcome this shortcoming, Curic et al. (1999) transformed industrial strains with an rDNA plasmid that encoded enzymes for branched-chain amino acid biosynthesis. Selection for naturally occurring aldB mutants among transformants can then be performed as outlined above, and food-grade variants of those cells are subse- quently obtained by plasmid curing. Starter bacteria derived by this strategy are natural mutants that lack any foreign DNA, and this feature has facilitated their commercial application in some countries, including the United States.

\section{Current Application of rDNA in Starter Technology}

Although cells containing rDNA molecules are not in commercial use, rDNA-based experiments in research laboratories continue to fuel important advancements in culture technology. This is because rDNA methods allow for the construction of strain derivatives that differ only by the action (null mutants) or activity (expression mutants) of a particular enzyme or metabolic pathway of interest. By comparing the phenotype of the wild-type bacterium to its isogenic derivative, the role of that enzyme or pathway in a given process can often be clearly defined. The complexity of the LAB proteolytic enzyme system, for example, has long confounded efforts to determine the role of individual enzymes in cheese proteolysis and maturation. However, construction of isogenic peptidase or proteinase mutants has allowed researchers to systematically determine the contribution of several enzymes on cell growth and cheese chemistry (Christensen et al., 1999; Sridhar et al., 2005; Broadbent and Steele, 2006). With this type of knowledge, dairy technologists can often use strain selection or screening methods to identify starter bacteria that already possess various traits of interest.

\section{Media Development for Selective Enumeration of $L A B$}

The health benefits derived by the consumption of foods containing acidophilus and bifidus products are well documented and more than 90 probiotic products are available worldwide. A number of health benefits have been claimed for probiotic bacteria (defined as live microorganisms, which, when administered in adequate amounts, confer a health benefit on the host) such as Lb. acidophilus, Bifidobacterium spp., and $L b$. casei. Because of this, these organisms are increasingly incorporated into dairy foods.

To provide health benefits, the suggested level for probiotic bacteria is $\geq 10^{6} \mathrm{cfu} / \mathrm{g}$ of product (Shah, 2000). However, studies have shown low viability of probiotics in market preparations (Shah et al., 1995; Shah, 2000). The need to monitor survival of Lb. acidophilus and Bifidobacterium in fermented products has often been neglected, with the result that a number of products reach the market containing low concentrations of viable bacteria (Shah et al., 1995). To assess viabil- 
ity and survival of probiotic bacteria, it is important to have good methods for selective enumeration of these probiotic organisms. Several media for selective enumeration of Lb. acidophilus and Bifidobacterium spp. have been proposed (Dave and Shah, 1996; Shah, 2000). However, most of these methods are based on pure cultures of these organisms. Similarly, there are only a few reports that have described selective enumeration of $L b$. case $i$ in the presence of other probiotic organisms and yogurt starter bacteria (Strep. thermophilus and Lb. delbrueckii ssp. bulgaricus; Champagne et al., 1997; Ravula and Shah, 1998). An important parameter in monitoring viable organisms to assess product quality is the ability to count $L b$. acidophilus, Bifidobacterium spp., and Lb. casei differentially. Selective enumeration of $L b$. reuteri, $L b$. plantarum, Lb. rhamnosus, and Propionibacterium has not been studied extensively.

\section{Selective Enumeration of Lb. acidophilus, Bifidobacterium spp., Lb. casei, Lb. rhamnosus, and Propionibacterium}

Yogurt is made from the symbiotic growth of Strep. thermophilus and Lb. delbrueckii ssp. bulgaricus. These bacteria do not survive the gastric passage or colonize the gut. Hence, the recent trend is to add Lb. acidophilus, Bifidobacterium spp., and Lb. casei to yogurt. Lactobacillus johnsonii and Lactobacillus crispatus have also been used in probiotic products. In some products such as cheese-based dips, the trend is to use other probiotic cultures such as Lb. rhamnosus and Propionibacterium.

Several media have been developed for differential enumeration of yogurt culture organisms ( $L b$. delbrueckii ssp. bulgaricus and Strep. thermophilus), including Lee's agar (Lee at al., 1974), and reinforced clostridial agar adjusted to $\mathrm{pH} 5.5$ (Johns et al., 1978). Several media have been suggested for the enumeration of Lb. acidophilus, including bile medium (Collins, 1978), Rogosa agar, MRS medium containing maltose, raffinose, or melibiose in place of dextrose (Hull and Roberts, 1984), cellobiose-esculin agar (Hunger, 1986), and agar medium based on X-Glu (Kneifel and Pacher, 1993).

Similarly, several selective media have been developed for enumeration of pure cultures of Bifidobacterium spp., including nalidixic acid-neomycin sulfatelithium chloride-paromomycin sulfate (NNLP) agar (Teraguchi et al., 1978; Munoa and Pares, 1988; Burford, 1989; Wijsman et al., 1989; Sozzi et al., 1990; Laroia and Martin, 1991; Onggo and Fleet, 1993; Arroyo et al., 1994). However, these media may not be suitable for selective enumeration of Bifidobacterium spp. in the presence of Lb. acidophilus and yogurt culture organisms. Furthermore, differences exist among the strains of the same species with respect to sugar fermentation characteristics and tolerance to low $\mathrm{pH}$ and bile. There is concern that some media that contain bile or antibiotics might also restrict the growth of Lb. acidophilus or Bifidobacterium and that counts obtained are not representative of the actual number of viable cells present in the product.

Selective enumeration of $L b$. casei in yogurt-type fermented milks containing probiotic bacteria based on $15^{\circ} \mathrm{C}$ incubation temperature and a $14 \mathrm{~d}$ incubation time was reported by Champagne and coworkers (1997). However, an incubation time of $14 \mathrm{~d}$ is not practical if the results are required in a short time.

Lankaputhra et al. (1996) proposed the use of MRSmaltose agar for selective enumeration of $L b$. acidophilus in the presence of yogurt organisms in a product that does not contain Bifidobacterium spp. Similarly, Lankaputhra and Shah (1996) developed a simple method for selective enumeration of Lb. acidophilus in the presence of yogurt starter bacteria and Bifidobacterium spp. based on differences in sugar fermentation patterns. Dave and Shah (1996) evaluated 15 media to determine their suitability for selective enumeration of Strep. thermophilus, Lb. delbrueckii ssp. bulgaricus, Lb. acidophilus, and Bifidobacterium using 5 to 6 strains of each of the 4 organisms. Streptococcus thermophilus (ST) agar was found to be suitable for selective enumeration of Strep. thermophilus under aerobic incubation at $37^{\circ} \mathrm{C}$ for $24 \mathrm{~h}$. de Man, Rogosa, and Sharpe agar at pH 5.2 or RCA at pH 5.3 was recommended for the enumeration of $L b$. delbrueckii ssp. bulgaricus; MRS-maltose agar could be used for enumerating total counts of $L b$. acidophilus and Bifidobacterium. For selective enumeration of $L b$. acidophilus, MRS-salicin agar or MRS-sorbitol agar could be used. For selective enumeration of Bifidobacterium, MRS-NNLP agar has been found to be suitable. However, checking the growth of pure cultures of Bifidobacterium in this medium is recommended before adopting them for enumeration purposes in the presence of yogurt cultures and $L b$. acidophilus.

There is little information on selective enumeration of $L b$. casei in yogurt and fermented milk drinks, which may contain yogurt starter organisms and probiotic bacteria. A selective medium known as $L b$. casei $(\mathbf{L C})$ agar has been developed by Ravula and Shah (1998) for enumeration of $L b$. casei populations from commercial yogurts and fermented milk drinks that may contain yogurt starter bacteria (Strep. thermophilus and $L b$. delbrueckii ssp. bulgaricus), Lb. acidophilus, Bifidobacterium spp., and $L b$. casei. The composition of LC agar is shown in Table 3. 
Table 3. Composition of Lactobacillus casei (LC) agar ${ }^{1}$

\begin{tabular}{lc}
\hline Ingredients & Amount $(\mathrm{g} / \mathrm{L})$ \\
\hline Bacteriological peptone & 10.00 \\
Yeast extract & 1.00 \\
Lab Lemco & 4.00 \\
$\mathrm{KH}_{2} \mathrm{PO}_{4}$ & 2.00 \\
Sodium acetate (trihydrate) $_{\text {Tri-ammonium citrate }}$ & 3.00 \\
Magnesium sulfate (hepta hydrate) & 1.00 \\
Magnesium sulfate (tetra hydrate) & 0.20 \\
Acid casein hydrolysate & 0.05 \\
Tween 80 & 1.00 \\
Bacteriological agar & 1.00 \\
\end{tabular}

${ }^{1}$ Source: Ravula and Shah (1998).

Tharmaraj and Shah (2003) evaluated 19 bacteriological media to assess their suitability to selectively enumerate $L b$. delbrueckii ssp. bulgaricus, Strep. thermophilus, Lb. casei, Lb. rhamnosus, Lb. acidophilus, Bifidobacterium, and Propionibacterium. Bacteriological media evaluated included ST, pH-modified MRS, MRS-vancomycin, MRS-bile, MRS-NaCl, MRS-lithium chloride, MRS-NNLP, RCA, sugar (including maltose, galactose, sorbitol, mannitol, esculin)-based, sodium lactate, arabinose, raffinose, xylose, and LC agars. Incubations were carried out under aerobic and anaerobic conditions at $27,30,37,43$, and $45^{\circ} \mathrm{C}$ for 24 and $72 \mathrm{~h}$ and 7 to $9 \mathrm{~d}$. The use of ST agar and aerobic incubation at $37^{\circ} \mathrm{C}$ for $24 \mathrm{~h}$ was suitable for Strep. thermophilus, whereas Lb. delbrueckii ssp. bulgaricus could be enumerated using MRS agar ( $\mathrm{pH} 4.58$ or 5.20) under anaerobic incubation at $45^{\circ} \mathrm{C}$ for $72 \mathrm{~h}$. The use of MRS-vancomycin agar and anaerobic incubation at $43^{\circ} \mathrm{C}$ for $72 \mathrm{~h}$ was suitable to enumerate $L b$. rhamnosus, and MRS-vancomycin agar and anaerobic incubation at $37^{\circ} \mathrm{C}$ for $72 \mathrm{~h}$ were selective for Lb. casei. Lactobacillus acidophilus could be enumerated using MRS agar at $43^{\circ} \mathrm{C}$ for $72 \mathrm{~h}$ or basal agar supplemented with maltose at $43^{\circ} \mathrm{C}$ for $72 \mathrm{~h}$ or basal-sorbitol agar at $37^{\circ} \mathrm{C}$ for $72 \mathrm{~h}$, under anaerobic conditions. Bifidobacterium could be enumerated on MRS-NNLP agar under anaerobic incubation at $37^{\circ} \mathrm{C}$ for $72 \mathrm{~h}$. Propionibacterium could be enumerated on sodium lactate agar under anaerobic incubation at $30^{\circ} \mathrm{C}$ for 7 to $9 \mathrm{~d}$. A subtraction method was most suitable for counting Propionibacterium in the presence of other LAB from a product. For this method, counts of LAB at d 3 on sodium lactate agar under anaerobic incubation at $30^{\circ} \mathrm{C}$ were subtracted from counts at $\mathrm{d} 7$ of LAB and Propionibacterium (Table 4).

In summary, MRS-salicin or MRS-sorbitol agar can be used for selective enumeration of Lb. acidophilus if $L b$. case $i$ is not added to the product. However, if Lb. casei is added to the product, then MRS-sorbitol agar or MRS-salicin agar can be used to obtain counts of $L b$. acidophilus and $L b$. casei, and LC agar can be used to obtain a total count of $L b$. casei. The counts of $L b$. casei can be subtracted from the total population of $L b$. acidophilus and $L b$. casei enumerated using MRS-salicin or MRS-sorbitol agar. Bifidobacterium could be enumerated on MRS-NNLP agar under anaerobic incubation at $37^{\circ} \mathrm{C}$ for $72 \mathrm{~h}$. Propionibacterium could be enumerated on sodium lactate agar under anaerobic incubation at $30^{\circ} \mathrm{C}$ for 7 to $9 \mathrm{~d}$. The ST agar could be used for selective enumeration of Strep. thermophilus, MRS agar ( $\mathrm{pH} 5.2$ ) is suitable for Lb. delbrueckii ssp. bulgaricus.

\section{THE ROLE OF PROBIOTICS IN MODULATION OF IMMUNE FUNCTION}

\section{Probiotics and Gastrointestinal Immune Function}

The term "probiotic," although not legally defined in many countries, refers to "microbial preparations that when ingested exert a positive influence on host health and physiology" (Tannock, 2002). Today, lactobacilli and bifidobacteria are the primary probiotics used in fermented dairy foods such as yogurt and dietary supplements. About a century ago, Metchnikoff (1907) wrote in his book, The Prolongation of Life, that consumption of fermented dairy products by LAB resulted in improved health and longer life. Today, an increasing number of health foods, functional foods, and pharmaceutical preparations are promoted with health claims based on the probiotic characteristics of some of these bacteria. It is widely accepted that the gastrointestinal microflora plays an important role in the health of the host and possesses immunomodulating capacity. However, exactly how a particular bacterial species contributes to the development of the immune system has not been systematically addressed. Probiotic ingestion is thought to alter the gastrointestinal microflora by providing bacterial cells to the gut ecosystem, and probiotics have been suggested as potential candidates for immune modulation. Various studies have been conducted on the effect of probiotic bacteria on immune function. However, many of the findings have been inconclusive or conflicting in the absence of clear mechanistic data. Improvement of the immune system due to probiotics have been attributed to strengthening of nonspecific defenses against infection, increased phagocytic activity of white blood cells, increase in IgA production, proliferation of intraepithelial lymphocytes, adjuvant effect in antigen-specific immune responses, regulation of the balance of $\mathrm{T}$ helper 1 (Th1) and T-helper 2 (Th2) cells (Mercenier et al., 2003). It is thought that the mechanism by which probiotics influence the immune system may be the ability to differentially modulate expression of cytok- 
Table 4. Media recommended for selective enumeration of Streptococcus thermophilus, Lactobacilus delbrueckii ssp. bulgaricus, Lactobacillus acidophilus, Bifidobacterium, Lactobacillus casei, Lactobacillus rhamnosus, and Propionibacterium and viable counts of in a mixture of bacteria

\begin{tabular}{|c|c|c|c|c|}
\hline Agar $^{1}$ & Bacteria & Incubation conditions & Colony morphology & $\begin{array}{l}\text { Viable } \\
\text { count } \\
\text { (cfu/mL) }\end{array}$ \\
\hline ST agar & S. thermophilus & Aerobic, $37^{\circ} \mathrm{C}, 24 \mathrm{~h}$ & $0.1-0.5 \mathrm{~mm}$, round yellowish & $3.9 \times 10^{4}$ \\
\hline MRS-sorbitol agar & L. acidophilus & Anaerobic, $37^{\circ} \mathrm{C}, 72 \mathrm{~h}$ & Rough, dull, small (0.1-0.5), brownish & $10.0 \times 10^{7}$ \\
\hline MRS-NNLP agar & Bifidobacterium & Anaerobic, $37^{\circ} \mathrm{C}, 72 \mathrm{~h}$ & $1 \mathrm{~mm}$, white, smooth, shiny & $7.0 \times 10^{7}$ \\
\hline MRS-vancomycin ggar $^{2}$ & L. casei & Anaerobic, $37^{\circ} \mathrm{C}, 72 \mathrm{~h}$ & $1.0 \mathrm{~mm}$, white shiny, smooth & $5.3 \times 10^{7}$ \\
\hline
\end{tabular}

${ }^{1} \mathrm{ST}=$ Streptococcus thermophilus; MRS = de Man, Rogosa, and Sharpe; MRS-NNLP = MRS plus nalidixic acid, neomycin sulfate, lithium chloride, and paromycin sulfate;

${ }^{2}$ If L. rhamnosus was not present; however, if L. rhamnosus was present, then subtraction methods could be used; that is, subtracting L. rhamnosus counts on MRS-vancomycin agar under anaerobic incubation at $43^{\circ} \mathrm{C}$ for $72 \mathrm{~h}$ from total counts of $L$. casei and $L$. rhamnosus obtained in MRS-vancomycin agar under anaerobic incubation at $37^{\circ} \mathrm{C}$ for $72 \mathrm{~h}$ ).

${ }^{3}$ Subtraction method could also be used to determine the counts of Propionibacterium; that is, counts of $L$. casei and $L$. rhamnosus (anaerobic incubation, $30^{\circ} \mathrm{C}, 72 \mathrm{~h}$ ) could be subtracted from counts of $L$. casei, L. rhamnosus, and Propionibacterium (anaerobic incubation, $\left.30^{\circ} \mathrm{C}, 7 \mathrm{~d}\right)$.

ines and costimulatory molecules (Miettinen et al., 1996; Tejada-Simon et al., 1996a,b; Marin et al., 1997a,b; Christensen et al., 2002). More recently, probiotics have been reported to modulate innate and acquired immune control and contribute to more finely tuned Th1 and Th2 immune responses. Of particular interest have been IL-10 and IL-12 as well as the expression of costimulatory molecules B7-1 (CD80) and B7-2 (CD86). Interleukins IL-10 and IL-12 exert opposite regulatory effects; IL-12 is a Th1-skewing cytokine that elicits IFN- $\gamma$ production by $\mathrm{T}$ cells and natural killer cells (Heufler et al., 1996), whereas IL-10 is an antiinflammatory cytokine that suppresses IL-12 production and thus IFN- $\gamma$ production, favoring a Th2 response (Heufler et al., 1996). Interleukin 10 can also down-regulate presentation of an antigen by blocking translocation of antigen-major histocompatibility complex (MHC) class II complex to the surface of the antigen-presenting cell. Interleukin 6 , another important regulatory cytokine, is produced by a wide variety of cells with antigen-presenting cells (APC) representing its primary source. It provides for terminal differentiation of B cells into plasma cells and has been reported to polarize naïve $\mathrm{CD}^{4+} \mathrm{T}$ cells to effector Th2 cells (Rincon et al., 1997). Tumor necrosis factor- $\alpha$ (TNF$\boldsymbol{\alpha}$ ), another cytokine produced by macrophages, is an important regulatory mediator (Goldsby et al., 2000).

\section{Antigen-Presenting Cells}

Antigen-presenting cells such as dendritic cells (DC) and macrophages are key components for Th1/Th2 immune responses. Dendritic cells are distributed in most tissues such as the mucosa of the GI tract (where they are found in Peyer's patches), lamina propria, and draining mesenteric lymph nodes; they are the principal stimulators of naïve T helper cells. The delicate balance between Th1 and Th2 immunity, as well as tolerance (Th3), is thought to be pivotally controlled by stimulating DC. The ability of activated DC to prime T-cell activity is, in addition to expression of MHC antigen complexes, due to DC expression of cytokines and costimulatory molecules that are up-regulated during maturation. The discriminative factors in this respect are production of the strong Th1-skewing cytokine, IL-12, as well as the expression of the costimulatory molecules B7-1 (CD80) and especially B7-2 (CD86). Dendritic cells found in the GI tract are close to the GI microbial environment. Thus, the intestinal flora including probiotics may exert immunoregulatory effects through modulation of the Th1/Th2/Th3promoting capacity of DC in the gut.

Like DC, macrophages are professional APC. They are capable of presenting antigen $\mathrm{CD}^{4+} \mathrm{T}$ cells with class II MHC molecules. They also provide costimulatory signals needed to provide T-cell activation that leads to proliferation and differentiation. However, they differ from DC in their ability to display antigen and in their ability to provide costimulatory signals. Macrophages are activated by phagocytosis of bacteria or by bacterial products such as LPS or by IFN- $\gamma$. Activated macrophages up-regulate their expression of class II MHC molecules and costimulatory B7 molecules. Activated macrophages are common activators of memory and effector T cells. Expression of MHC class II, as well as a second signal provided by the costimulatory B7 molecules CD80 and CD84, is required for effective antigen presentation. Activated 
macrophages may also secrete a variety of cytokines (Goldsby et al., 2000). Probiotics have been shown to differentially modulate expression and production of cytokines by macrophages.

\section{Toll-Like Receptors}

Activation of surface receptors called toll-like receptors (TLR) by bacterial components is believed to be key for regulation of immune responses and to mediate the link between innate and adaptive immunity. These receptors are able to recognize microbial particles and activate immune cells accordingly. Although the mechanism of TLR-mediated recognition of microbial particles is not well known, it is believed that it depends on the innate immune system to detect the presence of infectious microorganisms and to induce a set of endogenous signals, such as inflammatory cytokines and chemokines (Medzhitov and Janeway, 2000). These signals then activate antigen-specific lymphocytes and induce their differentiation into effector cells. Currently, 10 TLR have been identified (TLR1 to 10). Bacterial products activate TLR2, TLR4, TLR6, and TLR9 (Takeda et al., 2003). Receptor TLR2 forms a heterodimeric complex with either TLR1 or TLR6, and responds to bacterial peptidoglycan and lipopolypeptides, whereas TLR4, TLR5, and TLR9 recognize LPS, flagellin, and hypomethylated CpG-rich DNA, respectively. In general, TLR4 has been considered the major receptor for gram-negative bacteria, whereas TLR2 is considered the receptor for gram-positive bacteria (Takeuchi et al., 1999). The TLR are connected, via the adaptor protein MyD88, to a signal transduction mechanism that is utilized by all members of the family. They induce similar patterns of gene expression including those involving inflammatory responses. It is becoming increasingly clear, however, that certain signaling mechanisms are specific to individual TLR (Horng et al., 2002; Yamamoto et al., 2002), and different TLR agonists induce different patterns of gene expression (Hirschfeld et al., 2001; Jones et al., 2001; Re and Strominger, 2001).

\section{Nuclear Factor- $\kappa B$}

The triggering of APC through TLR initiates a signal transduction cascade that culminates in the activation of transcription factors such as nuclear factor (NF)$\kappa \mathrm{B}$, a major player in the inflammatory immune responses of the gut. In the noninflammatory state, NF$\kappa \mathrm{B}$ is bound to its inhibitor, $\mathrm{I} \kappa \mathrm{B}$, and is retained in the cytoplasm in its inactive form. When the appropriate signal is received to activate NF- $\kappa \mathrm{B}$, phosphorylation of $\mathrm{I} \kappa \mathrm{B}$ by $\mathrm{I} \kappa \mathrm{B}$ kinases $\alpha$ and $\beta$ (IKK $\alpha$ and $\operatorname{IKK} \beta$ ) results in its ubiquitination and degradation. The release of $\mathrm{NF}-\kappa \mathrm{B}$ (from the inhibited state) and its translocation to the nucleus results in transcriptional activation of cytokine and chemokine genes, which are important in inflammatory responses. A number of bacterial pathogens can activate NF- $\kappa \mathrm{B}$ and thus the inflammatory immune responses. More recently, Neish et al. (2000) have shown that nonpathogenic bacteria have evolved ways to selectively attenuate this pathway and hinder NF- $\kappa$ B activation. This has important implications for probiotics, in that probiotics may also be able to abrogate NF- $\kappa \mathrm{B}$ activation and block the host's inflammatory responses.

\section{Current Research}

Our initial work in the area of LAB and immune function involved evaluating representative strains of Lactobacillus spp. (16 strains), Bifidobacterium spp. (14 strains), and Streptococcus spp. (4 strains) on cytokine production using a macrophage model (RAW 264.7 cells) and T-helper-cell model (EL4.IL-2 thymoma cells; Marin et al., 1997a,b, 1998). Members of all 3 genera induced significant increases in IL- 6 and TNF- $\alpha$ production in unstimulated and LPS-stimulated RAW 264.7 macrophage cells. Bifidobacteria and some strains of lactobacilli also increased IL-2 production in EL-4 T cells but required a costimulatory signal and were less remarkable (Marin et al., 1997a,b, 1998). In ex vivo studies in which mice were gavaged with 1 $\times 10^{9}$ viable bacteria and peritoneal, Peyer's patch, and splenic leukocytes cultured in the presence and absence of inducing agents (LPS or phorbol 12-myristate- 13 acetate and ionomycin), we demonstrated that $L b$. acidophilus and $L b$. casei can potentiate IL- 6 and IL-12 production by peritoneal macrophages. Lactobacillus acidophilus also potentiated IFN- $\gamma$ and nitric oxide production. In contrast, Lb. helveticus, Lb. gasseri, Lb. reuteri, and Bifidobacterium spp. attenuated the production of IL- 6 , IFN- $\gamma$, and nitric oxide by peritoneal macrophages (Tejada-Simon et al., 1999).

We have also investigated the effects of yogurts (with or without Bifidobacterium spp. and Lb. acidophilus) ingestion ( 2 and $4 \mathrm{wk}$ ) on mucosal and systemic cytokine gene expression in the mouse (Ha et al., 1999). Relative mRNA levels in spleen, mesenteric lymph nodes, or Peyer's patches for the cytokines INF- $\gamma$, TNF$\alpha$, IL-2, IL-4, and IL-6 were determined. Prolonged feeding of some yogurts had no effect or decreased specific cytokine mRNA, in particular, proinflammatory TNF- $\alpha$ mRNA. Proinflammatory cytokines such as TNF- $\alpha$ activate a number of important cell-mediated processes that may contribute to the development of inflammatory diseases. Thus, it may be speculated 
that suppression of TNF- $\alpha$ expression by yogurt ingestion could actually reduce the severity of these diseases. In another study in which mice were fed probiotic yogurts containing $L b$. acidophilus and Bifidobacterium, we observed enhanced mucosal and systemic IgA response to the cholera toxin immunogen compared with mice fed conventional yogurt or nonfat dry milk control diets (Tejada-Simon et al., 1999).

We also reported on the effects of ingesting yogurts on lymphocyte populations in Peyer's patches and spleens in mice fed 3 different yogurts with or without Bifidobacterium and Lb. acidophilus (Pestka et al., 2001). After $14 \mathrm{~d}$ of feeding, spleen and Peyer's patch lymphocytes were subjected to phenotype analysis by flow cytometry. The percentages of $\mathrm{CD}^{4+}$ ( $\mathrm{T}$ helper) cells were significantly increased in the spleens from the group of mice fed yogurt containing Bifidobacterium spp. and Lb. acidophilus, and a similar trend was observed in the remaining 2 probiotic-supplemented yogurts. Effects on $\mathrm{CD}^{4+}$ populations were not observed in spleens of mice fed conventional yogurt or in Peyer's patches of any of the 4 yogurt groups.

More recently, Christensen et al. (2002) reported on cytokine expression and maturation of surface markers in murine DC as influenced by lactobacilli. There were significant differences among lactobacilli strains in their capacity to induce IL-12 and TNF- $\alpha$ production. Less pronounced differences were reported among lactobacilli in their induction of IL- 6 and IL10. Lactobacilli strains that had the greatest ability to induce IL-12 were most effective in up-regulating surface MHC class II and B7-2 (CD86), indicative of DC cell maturation. Furthermore, Lb. reuteri, which was a poor IL-12 inducer, inhibited IL-12, IL-6, and TNF- $\alpha$ induction by $L b$. casei; IL-10 production was unaffected. Both $L b$. reuteri and $L b$. casei induced upregulation of B7-2. These results provide significant insight as to how different Lactobacillus strains exert different DC activation patterns and potentially alter the Th1/Th2 balance. These data suggest that differential activation of TLR on accessory cells by bacterial components might explain the differences observed in cytokine induction by lactobacilli and the opposing results observed in immunological studies on gut microflora used to test this hypothesis. They also provide important insight to our previous results with cytokine gene expression and lymphocyte populations in mice in yogurt feeding studies.

In summary, our previous studies suggest that probiotics do not share the same immunomodulatory properties and may even have opposing effects when used in mixed culture systems. Thus, it may be possible through appropriate selection and blending of cul- tures to modulate innate immune control of Th1 and Th2 responses.

Most recently, we screened Lactobacillus salivarius Ls 33, Lb. acidophilus NCFM, and Lb. paracasei Lpc 37 for their ability to stimulate TLR by assessing NF$\kappa \mathrm{B}$ activation in HEK293 cells expressing a given TLR. The activity of the LAB was tested on 7 different TLR: TLR 2, 3, 4, 5, 7, 8, 9. Their effects were then compared with control ligands (known TLR agonists): heat-killed Listeria monocytogenes (TLR2), Poly(I:C) (TLR 3), Escherichia coli K12 LPS (TLR 4), Salmonella Typhimurium flagellin (TLR5), Loxoribine (TLR 7), ssPolyU (TLR8), and CpG ODN 2006 (TLR9). The 3 LAB had significant but different stimulatory effects on human (h) TLR2. Lactobacillus acidophilus NCFM had the highest stimulatory effect on hTLR2, followed by $L b$. paracasei and $L b$. salivarius. Their stimulatory effect was lower than the positive control (heat-killed L. monocytogenes). No additional stimulatory effect was evident at higher levels tested. These results were confirmed by flow cytometry using RAW 264.7 macrophage cells. We also tested the hypothesis that probiotic LAB may prevent Salmonella Dublin-induced NF- $\kappa$ B translocation to the nucleus and prevent signal transduction; thus, its role in the inflammatory process in mouse intestinal epithelial cells. Western blots showed that $S$. Dublin induced translocation of $\mathrm{NF}-\kappa \mathrm{B}$ to the nucleus in $15 \mathrm{~min}$, increasing at $30 \mathrm{~min}$, and decreasing significantly in $90 \mathrm{~min}$. When $S$. Dublin-treated intestinal cells were cotreated with either $L b$. casei or $L b$. reuteri, the $\mathrm{LAB}$ able to inhibit most of the translocation at $30 \mathrm{~min}$. Lactobacillus reuteri was more effective than $L b$. casei; the nuclear translocation induced by $S$. Dublin was inhibited approximately $50 \%$ by $L b$. casei and $100 \%$ by $L b$. reuteri.

We further investigated the ability of $L b$. acidophilus NCFM to induce IL-10 and IL-12 production in vitro using RAW 264.7 macrophage cells and in vivo using mice. Lactobacillus acidophilus NCFM was a strong inducer of IL-12 in vitro and in murine spleen and bone marrow macrophages suggesting that it is a strong Th2 promoter. We also tested $L b$. paracasei Lpc 37 in vitro. This organism was also a good inducer of IL-12 but not to the extent of Lb. acidophilus NCFM.

In summary, although much has been published on the subject of probiotics and immune function, a clear picture has not yet fully emerged because of the strainspecific effects, different experimental models used, and the different immune responses studied (intestinal and systemic) in the body fluids or the cells (innate or acquired). The significance of the results varies widely. Furthermore, with fermented dairy products, the metabolites produced by the fermentation process 
may also exert immunomodulatory activity, which further complicates the research.

Probiotics remain in transit in the gastrointestinal system for variable periods, and it is commonly believed that the probiotic effect will be more likely to occur if the bacteria remain alive for as long as possible and are present in a sufficiently large quantity. To achieve and maintain an effect, the probiotic must be repeatedly administered to ensure a sufficient population level over time.

\section{REFERENCES}

Amarita, F., T. Requena, G. Taborda, L. Amigo, and C. Pelaez. 2001. Lactobacillus casei and Lactobacillus plantarum initiate catabolism of methionine by transamination. J. Appl. Microbiol. 90:971-978.

Antonsson, M., G. Molin, and Y. Ardo. 2003. Lactobacillus strains isolated from Danbo cheese as adjunct cultures in a cheese model system. Int. J. Food Microbiol. 85:159-169.

Arroyo, L., L. N. Cotton, and J. H. Martin. 1994. Evaluation of media for enumeration of Bifidobacterium adolescentis, B. infantis and B. longum from pure culture. Cult. Dairy Prod. J. 29:2-24.

Baruzzi, F., M. Morea, A. Matarante, and P. S. Cocconcelli. 2000. Changes in the Lactobacillus community during Ricotta Forte cheese natural fermentation. J. Appl. Microbiol. 89:807-814.

Beresford, T., and A. Williams. 2004. The microbiology of cheese ripening. Pages 287-318 in Cheese: Chemistry, Physics and Microbiology. 3rd ed. P. F. Fox, P. L. H. McSweeney, T. M. Cogan, and T. P. Guinee, ed. Elsevier, Amsterdam, the Netherlands.

Berthier, F., E. Beuvier, A. Dasen, and R. Grappin. 2001. Origin and diversity of mesophilic lactobacilli in Comte cheese, as revealed by PCR with repetitive and species-specific primers. Int. Dairy J. 11:293-305.

Bolotin, A., B. Quinquis, P. Renault, A. Sorokin, S. D. Ehrlich, S. Kulakauskas, A. Lapidus, E. Goltsman, M. Mazur, G. D. Pusch, M. Fonstein, R. Overbeek, N. Kyprides, B. Purnelle, D. Prozzi, K. Ngui, D. Masuy, F. Hancy, S. Burteau, M. Boutry, J. Delcour, A. Goffeau, and P. Hols. 2004. Complete sequence and comparative genome analysis of the dairy bacterium Streptococcus thermophilus. Nat. Biotechnol. 22:1554-1558.

Bolotin, A., P. Wincker, S. Mauger, O. Jaillon, K. Malarme, J. Weissenbach, D. Ehrlich, and A. Sorokin. 2001. The complete genome sequence of the lactic acid bacterium Lactococcus lactis ssp. lactis IL1403. Genome Res. 11:731-753.

Broadbent, J. R. 2001. Genetics of lactic acid bacteria. Pages 243299 in Applied Dairy Microbiology. 2nd ed. J. L. Steele and E. H. Marth, ed. Marcel Dekker Inc., New York, NY.

Broadbent, J. R., and J. L. Steele. 2007. Proteolytic enzymes of lactic acid bacteria and their influence on bitterness in bacterialripened cheeses. In Flavor of Dairy Products. K. R. Caldwaller, M. A. Drake, and R. J. McGorrin, ed. Am. Chem. Soc., Washington, DC.

Broome, M. C., D. A. Krause, and M. W. Hickey. 1990. The use of non-starter lactobacilli in Cheddar cheese manufacture. Aust. J. Dairy Tech. 45:67-73.

Brüssow, H., A. Bruttin, F. Desiere, S. Lucchini, and S. Foley. 1998. Molecular ecology and evolution of Streptococcus thermophilus bacteriophages-A review. Virus Genes 16:95-109.

Burford, M. Y. 1989. Enumeration of Lactobacillus acidophilus and Bifidobacterium in milk + using oxygen-reducing membrane fraction. Cult. Dairy Prod. J. 24:21-23.

Capra, M. L., A. Del, L. Quiberoni, H. W. Ackermann, S. Moineau, and J. A. Reinheimer. 2006. Characterization of a new virulent phage (MLC-A) of Lactobacillus paracasei. J. Dairy Sci. 89:2414-2423.

Champagne, C. P., D. Roy, and A. Lafond. 1997. Selective enumeration of Lactobacillus casei in yoghurt-type fermented milks based on a $15^{\circ} \mathrm{C}$ incubation temperature. Biotechnol. Tech. 11:567-569.

Christensen, H., H. Frokiaer, and J. J. Pestka. 2002. Lactobacilli differentially modulate expression of cytokines and maturation surface markers in murine dentritic cells. J. Immunol. 168:171-178.

Christensen, J. E., E. G. Dudley, J. A. Pederson, and J. L. Steele. 1999. Peptidases and amino acid catabolism in lactic acid bacteria. Antonie Van Leeuwenhoek 76:217-246.

Collins, E. B. 1978. Enumeration of Lactobacillus acidophilus with the agar plate count. J. Food Prot. 41:439-442.

Collins, M. D., B. A. Phillips, and P. Zanoni. 1989. Deoxyribonucleic acid homology studies of Lactobacillus casei, Lactobacillus paracasei sp. nov., subsp. paracasei and subsp. tolerans and Lactobacillus rhamnosus sp. nov., comb. nov. Int. J. Syst. Bacteriol. 39:105-108.

Crow, V., B. Curry, and M. Hayes. 2001. The ecology of non-starter lactic acid bacteria (NSLAB) and their use as adjuncts in New Zealand Cheddar. Int. Dairy J. 11:275-283.

Crow, V. L. 1986. Metabolism of aspartate by Propionibacterium freundenreichii subsp. shermanii: Effect of lactate fermentation. Appl. Environ. Microbiol. 52:359-365.

Curic, M., B. Stuer-Lauridsen, P. Renault, and D. Nilsson. 1999. A general method for selection of $\alpha$-acetolactate decarboxylasedeficient Lactococcus lactis mutants to improve diacetyl formation. Appl. Environ. Microbiol. 65:1202-1206.

Dave, R. I., and N. P. Shah. 1996. Evaluation of media for selective enumeration of Streptococcus thermophilus, Lactobacillus delbrueckii ssp. bulgaricus, Lactobacillus acidophilus and Bifidobacterium spp. J. Dairy Sci. 79:1529-1536.

de Vos, W. M. 1996. Metabolic engineering of sugar catabolism in lactic acid bacteria. Antonie Van Leeuwenhoek 70:223-242.

deAngelis, M., A. Corsetti, N. Tosti, M. R. Corbo, and M. Gobbetti. 2001. Characterization of non-starter lactic acid bacteria from Italian ewe cheeses baseed on phenotypic, genotypic and cell wall protein analyses. Appl. Environ. Microbiol. 67:2011-2020.

Dellaglio, F., G. E. Felis and S. Torriani. 2002. The status of the species Lactobacillus casei (Orla Jensen 1916) Hansen and Lessel 1971 and Lactobacillus paracasei Collins et al. 1989. Request for an opinion. Int. J. Syst. Evol. Microbiol. 52:285-287.

Dicks, L. M. T., E. M. Duplessis, F. Dellaglio, and E. Lauer. 1996. Reclassification of Lactobacillus casei subsp. casei ATCC 393 and Lactobacillus rhamnosus ATCC 15820 as Lactobacillus zeae nom. rev., designation of ATCC 334 as the neotype of $L$. casei subsp. casei and rejection of the name Lactobacillus paracasei. Int. J. Syst. Bacteriol. 46:337-340.

Dudley, E. G., and J. L. Steele. 2005. Succinate production and citrate catabolism by Cheddar cheese nonstarter lactobacilli. J. Appl. Microbiol. 98:14-23.

Duthoit, F., J. J. Godon, and M. C. Montel. 2003. Bacterial community dynamics during production of registeres designation of origin Salers cheeses as evaluated by 16S rRNA gene single strand conformation polymorphism analysis. Appl. Environ. Microbiol. 69:3840-3848.

Ferain, T., J. N. Hobbs, J. Richardson, D. Garmyn, P. Hols, N. E. Allen, and J. Delcour. 1996. Knockout of the two ldh genes has a major impact on peptidoglycan precursor synthesis in Lactobacillus plantarum. J. Bacteriol. 178:5431-5437.

Fitzsimons, N. A., T. M. Cogan, S. Condon, and T. Beresford. 1999. Phenotypic and genotypic characterization of non-starter lactic acid bacteria in mature cheddar cheese. Appl. Environ. Microbiol. 65:3418-3426.

Fox, P. F., T. P. Guinee, T. M. Cogan, and P. L. H. McSweeney. 2000. Fundamentals of Cheese Science. Aspen Publishers, Gaithersburg, MD.

Fox, P. F., and P. L. H. McSweeney. 2004. Cheese: An overview. Pages 1-18 in Cheese: Chemistry, Physics, and Microbiology. 3rd ed. Elsevier Academic Press, Oxford, UK.

Fox, P. F., P. L. H. McSweeney, and C. M. Lynch. 1998. Significance of non-starter lactic acid bacteria in Cheddar cheese. Aust. J. Dairy Technol. 53:83-89. 
Franz, C. M. A. P., W. H. Holzapfel, and M. E. Stiles. 1999. Enterococci at the crossroads of food safety. Int. J. Food Microbiol. 47:1-14.

Garvey, P., D. van Sinderen, D. P. Twomey, C. Hill, and G. F. Fitzgerald. 1995. Molecular genetics of bacteriophage and natural phage defense systems in the genus Lactococcus. Int. Dairy J. 5:905-947.

Goffin, P., M. Deghorain, J. L. Mainardi, I. Tytgat, M. C. Champomier-Verges, M. Kleerebezem, and P. Hols. 2005. Lactate racemization as a rescue pathway for supplying D-lactate to the cell wall biosynthesis machinery in Lactobacillus plantarum. J. Bacteriol. 187:6750-6761.

Goldsby, R. A., T. J. Kindt, and B. A. Osborne, ed. 2000. Immunology. Freeman and Company, New York, NY.

Goupil-Feuillerat, N., M. Cocaign-Bousquet, J.-J. Godon, S. D. Ehrlich, and P. Renault. 1997. Dual role of $\alpha$-acetolactate decarboxylase in Lactococcus lactis subsp. lactis. J. Bacteriol. 179:6285-6293.

Gumalla, S., and J. R. Broadbent. 1999. Tryptophan catabolism by Lactobacillus casei and Lactobacillus helveticus cheese flavor adjuncts. J. Dairy Sci. 82:2070-2077.

Gumalla, S., and J. R. Broadbent. 2001. Tyrosine and phenylalanine catabolism by Lactobacillus cheese flavor adjuncts. J. Dairy Sci. 84:1011-1019.

Ha, C. L., J. H. Lee, H. R. Zhou, Z. Ustunol, and J. J. Pestka. 1999. Effects of yogurt ingestion on mucosal and systemic cytokine gene expression in the mouse. J. Food Prot. 62:181-188.

Heufler, C., F. Koch, U. Stanzl, G. Topar, M. Wysocka, G. Trinchieri, A. Enk, R. M. Steinman, N. Romani, and G. Schuler. 1996. Interleukin-12 is produced by dendritic cells and mediates $\mathrm{T}$ helper 1 development as well as interferon- $\gamma$ production by $\mathrm{T}$ helper 1 cells. Eur. J. Immunol. 26:659-664.

Hirschfeld, M., J. J. Weis, V. Toshchakov, C. A. Salkowski, M. J. Cody, D. C. Ward, N. Qureshi, S. M. Michalek, and S. N. Vogel. 2001. Signaling by Toll-like receptor 2 and 4 agonists results in differential gene expression in murine macrophages. Infect. Immun. 69:1477-1482.

Horng, T., G. M. Barton, R. A. Flavell, and R. Medzhitov. 2002. The adopter molecule TIRAP provides signaling specificity to Tolllike receptors. Nature 420:329-333.

Hull, R. R., and A. V. Roberts. 1984. Differential enumeration of Lactobacillus acidophilus in yoghurt. Aust. J. Dairy Technol. 39:160-163.

Hunger, W. 1986. Aesculin-cellobiose agar for the isolation and counting of Lactobacillus acidophilus. Milchwissenschaft 41:283-285.

International Dairy Foods Association (IDFA). 2006. Cultured Dairy Products Report. IDFA, Washington, DC.

Johns, F. E., J. F. Gordon, and N. Shapton. 1978. The separation from yogurt cultures of Lactobacilli and Streptococci using reinforced clostridial agar at $\mathrm{pH} 5.5$ and plate count agar incorporating milk. J. Soc. Dairy Technol. 31:209-212.

Jones, B. W., T. Means, K. A. Heldwein, M. Keen, P. J. Hill, J. T. Belisle, and M. J. Fenton. 2001. Different toll-like receptor agonists induce distinct macrophage responses. J. Leukoc. Biol. 60:1036-1044.

Jordan, K. N., and T. M. Cogan. 1993. Identification and growth of non-starter lactic acid bacteria in Irish Cheddar cheese. Irish J. Agric. Food Res. 32:47-55.

Jordan, K. N., and T. M. Cogan. 1999. Heat resistance of Lactobacillus spp. isolated from Cheddar cheese. Lett. Appl. Microbiol. 29:136-140.

Kaneuchi, C., M. Seki, and K. Kamagata. 1988. Production of succinic acid from citric acid and related acids by Lactobacillus strains. Appl. Environ. Microbiol. 54:3053-3056.

Kang, O. J., L. P. Vezinz, S. Laberge, and R. E. Simard. 1998. Some factors influencing autolysis of Lactobacillus bulgaricus and Lactobacillus casei. J. Dairy Sci. 81:639-646.

Kashige, N., Y. Nakashima, F. Miake, and K. Watanabe. 2000. Cloning, sequence analysis and expression of Lactobacillus casei phage Pl-1 lysis genes. Arch. Virol. 145:1521-1534.
Khalid, N. M., and E. H. Marth. 1990. Proteolytic activity by strains of Lactobacillus plantarum and Lactobacillus casei. J. Dairy Sci. 73:3068-3076.

Kieronczyk, A., S. Skeie, T. Langsrud, and M. Yvon. 2003. Cooperation between Lactococcus lactis and nonstarter lactobacilli in the formation of cheese aroma from amino acids. Appl. Environ. Microbiol. 69:734-739.

Klaenhammer, T. R., and G. F. Fitzgerald. 1994. Bacteriophages and bacteriophage resistance. Pages 106-168 in Genetics and Biotechnology of Lactic Acid Bacteria. M. J. Gasson and W. M. De Vos, ed. Blackie Academic and Professional, London, UK.

Kneifel, W., and B. Pacher. 1993. An X-Glu based agar medium for the selective enumeration of $L$. acidophilus in yogurt related milk products. Int. Dairy J. 3:277-291.

Laht, T. M., S. Kask, P. Elias, K. Adamberg, and T. Paalme. 2002. Role of arginine in the development of secondary microflora in Swiss-type cheese. Int. Dairy J. 12:831-840.

Lankaputhra, W. E. V., and N. P. Shah. 1996. A simple method for selective enumeration of Lactobacillus acidophilus in yoghurt supplemented with L. acidophilus and Bifidobacterium spp. Milchwissenschaft 51:446-451.

Lankaputhra, W. E. V., N. P. Shah, and M. L. Britz. 1996. Evaluation of media for selective enumeration of Lactobacillus acidophilus and Bifidobacterium spp. Food Australia 48:113-118.

Laroia, S., and J. H. Martin. 1991. Methods for enumerating and propagating bifidobacteria. Cult. Dairy Prod. J. 26:32-33.

Lee, S. Y., E. R. Vedamuthu, and C. J. Washam. 1974. An agar medium for the differential enumeration of yoghurt starter bacteria. J. Milk Food Technol. 37:272-276.

Leuschner, R. G. K., and W. P. Hammes. 1998. Degradation of histamine and tyramine by Brevibacterium linens during surface ripening of Munster cheese. J. Food Prot. 61:874-878.

Lindgren, S. E., L. T. Axelsson, and R. F. McFeeters. 1990. Anaerobic L-lactate degradation by Lactobacillus plantarum. FEMS Microbiol. Lett. 66:209-214.

Lynch, C. M., P. L. H. McSweeney, P. F. Fox, T. M. Cogan, and F. D. Drinan. 1996. Manufacture of Cheddar cheeses with and without adjunct lactobacilli under controlled microbiological conditions. Int. Dairy J. 6:851-867.

Makarova, K., A. Slesarev, Y. Wolf, A. Sorokin, B. Mirkin, E. Koonin, A. Pavlov, N. Pavlova, V. Karamychev, N. Polouchine, V. Shakhova, I. Grigoriev, Y. Lou, D. Rohksar, S. Lucas, K. Huang, D. M. Goodstein, T. Hawkins, V. Plengvidhya, D. Welker, J. Hughes, Y Goh, A. Benson, K. Baldwin, J.-H. Lee, I. Díaz-Muñiz, B. Dosti, V. Smeianov, W. Wechter, R. Barabote, G. Lorca, E. Altermann, R. Barrangou, B. Ganesan, Y. Xie, H. Rawsthorne, D. Tamir, C. Parker, L. McKay, F. Breidt, J. Broadbent, R. Hutkins, D. O'Sullivan, J. Steele, G. Unlu, M. Saier, T. Klaenhammer, P. Richardson, S. Kozyavkin, B. Weimer, and D. Mills. 2006. Comparative genomics of the lactic acid bacteria. Proc. Natl. Acad. Sci. USA 103:15611-15616.

Marin, M. L., J. H. Lee, J. Murtha, Z. Ustunol, and J. J. Pestka. 1997a. Effects of Lactobacillus spp. on cytokine production by RAW 264.7 macrophage and EL-4 thymoma cell lines. J. Food Prot. 60:1364-1370.

Marin, M. L., M. V. Tejada-Simon, J. Murtha, Z. Ustunol, and J. J. Pestka. 1997b. Differential cytokine production in clonal macrophage and T-cell lines cultured with bifidobacteria. J. Dairy Sci. 80:2713-2720.

Marin, M. L., M. V. Tejada-Simon, J. H. Lee, J. Murtha, Z. Ustunol, and J. J. Pestka. 1998. Stimulation of cytokine production in clonal macrophage and T cell models by Streptococcus thermophilus: Comparison with Bifidobacterium sp. and Lactobacillus bulgaricus. J. Food Prot. 61:859-864.

McSweeney, P. L. H., P. F. Fox, J. A. Lucey, K. N. Jordan, and T. M. Cogan. 1993. Contribution of the indigenous microflora to the maturation of Cheddar cheese. Int. Dairy J. 3:613-634

Medzhitov, R., and C. Janeway. 2000. Innate immune recognition: Mechanisms and pathways. Immunol. Rev. 173:89-96.

Mercenier, A., S. Pavan, and B. Pot. 2003. Probiotic as biotherapeutic agents: Present knowledge and future prospects. Curr. Pharm. Des. 8:99-110. 
Metchnikoff, E. 1907. Prolongation of life: Optimistic studies. William Heinemann, London, UK.

Miettinen, M., J. Vuopio, and K. Varkila. 1996. Production of human tumor necrosis factor $\alpha$, interleukin-6, and interleukin-10 is induced by lactic acid bacteria. Infect. Immun. 64:5403-5410.

Munoa, F. J., and R. Pares. 1988. Selective medium for isolation and enumeration of Bifidobacterium spp. Appl. Environ. Microbiol. $54: 1715-1718$.

Naes, H., and J. Nissen-Meyer. 1992. Purification and N-terminal amino acid sequence determination of the cell-wall bound proteinase from Lactobacillus paracasei subsp. paracasei. J. Gen. Microbiol. 138:313-318.

Neish, A., A. T. Gewirtz, H. Zeng, A. N. Young, M. E. Hobert, V. Karmali, A. S. Rao, and J. L. Madara. 2000. Prokaryotic regulation of epithelia responses by inhibition of $\mathrm{I} \kappa \mathrm{B}-\alpha$ ubiquitination. Science 289:1560-1563.

Nierop Groot, M. N., and J. A. M. de Bont. 1998. Conversion of phenylalanine to benzaldehyde initiated by an aminotransferase in Lactobacillus plantarum. Appl. Environ. Microbiol. 64:3009-3013.

Ogier, J. C., O. Son, A. Gruss, P. T. Ailliez, and A. Delacroix-Buchet. 2002. Identification of the bacterial microflora in dairy products by temporal temperature gradient gel electrophoresis. Appl. Environ. Microbiol. 68:3691-3701.

Onggo, I., and G. H. Fleet. 1993. Media for the isolation and enumeration of lactic acid bacteria from yoghurts. Aust. J. Dairy Technol. 48:89-92.

Oude Elferink, S. J. W. H., J. Krooneman, J. C. Gottschal, S. F. Spoelstra, F. Faber, and F. Driehuis. 2001. Anaerobic conversion of lactic acid to acetic acid and 1,3-propanediol by Lactobacillus buchneri. Appl. Environ. Microbiol. 67:125-132.

Palles, T., T. Beresford, S. Condon, and T. M. Cogan. 1998. Citrate metabolism in Lactobacillus casei and Lactobacillus plantarum. J. Appl. Microbiol. 85:147-154.

Pestka, J. J., C. L. Ha, R. W. Warner, J. H. Lee, and Z. Ustunol. 2001. Effects of ingestion of yogurts containing Bifidobacterium and Lactobacillus acidophilus on spleen and Peyer's patch lymphocyte populations in the mouse. J. Food Prot. 64:392-395.

Peterson, S. D., and R. T. Marshall. 1990. Nonstarter lactobacilli in Cheddar cheese: A review. J. Dairy Sci. 73:1395-1410.

Poolman, B. 1993. Energy transduction in lactic acid bacteria. FEMS Microbiol Rev. 12:125-148.

Puchades, R., L. Lemieux, and R. E. Simard. 1989. Evolution of free amino acids during the ripening of Cheddar cheese containing added lactobacilli strains. J. Food Sci. 54:885-888.

Ravula, R. R., and N. P. Shah. 1998. Selective enumeration of Lactobacillus casei from yogurt and fermented milk drinks. Biotechnol. Tech. 12:819-822.

Re, F., and J. L. Strominger. 2001. Toll-like receptor 2 (TLR2) and TLR4 differentially activate human dendritic cells. J. Biol. Chem. 276:37692-37699.

Rea, M. C., C. M. A. P. Franz, W. H. Holzapfel, and T. M. Cogan. 2004. Development of enterococci and production of tyramine during the manufacture and ripening of Cheddar cheese. Irish J. Agric. Food Res. 43:247-258.

Rincon, M., J. Anguita, T. Nakamura, E. Fikrig, and R. A. Flavell. 1997. Interleukin (IL)-6 directs the differentiation of IL-4 producing CD4+ T cells. J. Exp. Med. 185:461-467.

Ryan, M. P., M. C. Rea, C. Hill, and R. P. Ross. 1996. An application in Cheddar cheese manufacture for a strain of Lactococcus lactis producing a novel broad-spectrum bacteriocin, lacticin 3147 . Appl. Environ. Microbiol. 62:612-619.

Sanchez, I., S. Sesena, J. M. Poveda, L. Cabezas, and L. Palop. 2005. Phenotypic and genotypic characterization of lactobacilli isolated from Spanish goat cheeses. Inter. J. Food Microbiol. 102:355-362.

Sanders, M. E., P. J. Leonhard, W. D. Sing, and T. R. Klaenhammer. 1986. Conjugal strategy for construction of fast acid-producing, bacteriophage-resistant lactic streptococci for use in dairy fermentations. Appl. Environ. Microbiol. 52:1001-1007.

Shah, N. P. 2000. Probiotic bacteria: Selective enumeration, and survival in dairy foods. J. Dairy Sci. 83:1-14.
Shah, N. P., W. E. V. Lankaputhra, M. Britz, and W. S. A. Kyle. 1995. Survival of L. acidophilus and Bifidobacterium bifidum in commercial yoghurt during refrigerated storage. Int. Dairy J. 5:515-521.

Smeianov, V. V., P. Wechter, J. R. Broadbent, J. E. Hughes, B. Rodríguez, and J. L. Steele. 2007. Comparative high-density microarray analysis of gene expression during growth of Lactobacillus helveticus in milk vs. rich culture medium. Appl. Environ. Microbiol. 71:3025-3032.

Somers, E. B., M. E. Johnson, and A. C. L. Wong. 2001. Biofilm formation and contamination of cheese by nonstarter lactic acid bacteria in the dairy environment. J. Dairy Sci. 84:1926-1936.

Sozzi, T., P. Brigidi, O. Mignot, and D. Matteuzzi. 1990. Use of dicloxacillin for the isolation and counting of Bifidobacterium from dairy products. Lait 70:357-361.

Sridhar, V. R., J. E. Hughes, D. L. Welker, J. R. Broadbent, and J. L. Steele. 2005. Identification and functional analysis of endopeptidase genes from the genomic sequence of Lactobacillus helveticus CNRZ 32. Appl. Environ. Microbiol. 71:3025-3032.

Strom, K., J. Sjögren, A. Broberg, and J. Schnürer. 2002. Lactobacillus plantarum MiLAB 393 produces the antifungal cyclic dipeptides cyclo(L-phe-L-pro) and cyclo(L-phe-trans-4-OH-L-pro) and 3 phenyllactic acid. Appl. Environ. Microbiol. 68:4322-4327.

Sumner, S. S., M. C. Speckhard, E. B. Sumers, and S. L. Taylor. 1985. Isolation of histamine producing Lactobacillus buchneri from Swiss cheese implicated in a food poisoning outbreak. Appl. Environ. Microbiol. 50:1094-1096.

Swearingen, P. A., D. J. O'Sullivan, and J. J. Warthesen. 2001. Isolation, characterization, and influence of native nonstarter lactic acid bacteria on Cheddar cheese quality. J. Dairy Sci. 84:50-59.

Swindell, S. R., K. H. Benson, H. G. Griffin, P. Renault, S. D. Ehrlich, and M. J. Gasson. 1996. Genetic manipulation of the pathway for diacetyl metabolism in Lactococcus lactis. Appl. Environ. Microbiol. 62:2641-2643.

Takeda, K., T. Kaisho, and S. Akira. 2003. Toll-like receptors. Annu. Rev. Immunol. 21:335-376.

Takeuchi, O., K. Hoshino, T. Kawai, H. Sanjo, H. Takada, T. Ogawa, K. Takeda, and S. Akira. 1999. Differential role of TLR2 and TLR4 in recognition of gram-negative and gram-positive bacterial cell wall components. Immunity 11:443-451.

Tannock, G. 2002. Probiotics and Prebiotics - Where are we going? G. Tannock (ed). Caister Academic Press, Wymondham, UK.

Tanous, C., A. Kieronczyk, S. Helinck, E. Chambellon and M. Yvon. 2002. Glutamate dehydrogenase activity: A major criterion for the selection of flavour producing lactic acid bacterial strains. Antonie van Leeuwenhoek 82:271-278.

Tejada-Simon, M. V., J. H. Lee, Z. Ustunol, and J. J. Pestka. 1999a. Ingestion of yogurt containing Lactobacillus acidophilus and Bifidobacterium to potentiate immunoglobulin A response to cholera toxin in mice. J. Dairy Sci. 82:649-660.

Tejada-Simon, M. V., Z. Ustunol, and J. J. Pestka. 1999b. Ex vivo effects of lactobacilli, streptococci and bifidobacteria ingestion on cytokine and nitric oxide production in a murine model. J. Food Prot. 62:162-169.

Teraguchi, S., M. Uehara, K. Ogasa, and T. Mitsuoka. 1978. Enumeration of bifidobacteria in dairy products. Jpn. J. Bacteriol. $33: 753-761$.

Tharmaraj, N., and N. P. Shah. 2003. Selective enumeration of Lactobacillus delbrueckii ssp. bulgaricus, Streptococcus thermophilus, Lactobacillus acidophilus, bifidobacteria, Lactobacillus casei, Lactobacillus rhamnosus and Propionibacteria. J. Dairy Sci. 86:2288-2296.

Thomas, T. D. 1987. Acetate production from lactate and citrate by non-starter bacteria in Cheddar cheese. N.Z. J. Dairy Sci. Technol. 22:25-38.

Tzanetakis, N., E. Litoppoulou-Tzanetaki, and A. Vafopoulou-Mastrojiannaki. 1991. Effect of Pediococcus pentosaceus on microbiology and chemistry of Teleme cheese. Lebens. Wiss. Technol. 24:173-176. 
van de Guchte, M., S. Penaud, C. Grimaldi, V. Barbe, K. Bryson, P. Nicolas, C. Robert, S. Oztas, S. Mangenot, A. Couloux, V. Loux, R. Dervyn, R. Bossy, A. Bolotin, J.-M. Batto, T. Walunas, J.-F. Gibrat, P. Bessieres, J. Weissenbach, S. D. Ehrlich, and E. Maguin. 2006. The complete genome sequence of Lactobacillus bulgaricus reveals extensive and ongoing reductive evolution. Proc. Natl. Acad. Sci. USA 103:9274-9279.

Vasquez, A., G. Molin, B. Pettersson, M. Antonsson, and S. Ahrne. 2005. DNA-based classification and sequence heterogeneities in the 16S rRNA genes of Lactobacillus casei / paracasei and related species. Syst. Appl. Microbiol. 28:430-441.

Westby, A., L. Nuraida, J. D. Owens, and P. A. Gibbs. 1993. Inability of Lactobacillus plantarum and other lactic acid bacteria to grow on D-ribose as sole source of fermentable carbohydrate. J. Appl. Bacteriol. 75:168-175.

Wijsman, M. R., L. P. Johanna, M. Hereijgers, and J. M. F. H. Groote. 1989. Selective enumeration of bifidobacteria in fermented dairy products. Neth. Milk Dairy J. 43:395-405.

Yamamoto, M., S. Sato, H. Hemmi, H. Sanjo, S. Uematsu, T. Kaisho, K. Hoshino, O. Takeuchi, M. Kobayashi, T. Fujita, K. Takeda, and S. Akira. 2002. Essential role for TIRAP in activation of the signaling cascade shared by TLR2 and TLR4. Nature 420:324-328.

Yvon, M., S. Berthelot, and J. C. Gripon. 1998. Adding $\alpha$-ketoglutarate to semi-hard cheese curd highly enhances the conversion of amino acids to aroma compounds. Int. Dairy J. 8:889-898. 